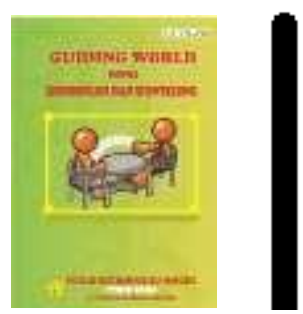

DOI: 10.33627

\title{
Korelasi Antara Lingkungan Keluarga Dengan Kemandirian Belajar Siswa Di SMP Negeri 7 Kota Bima
}

\author{
Sulistia Indah, Alya Nurmaya, Khairunnisa \\ Prodi Bimbingan dan Konseling, Sekolah Tinggi Keguruan Dan Ilmu Pendidikan (STKIP) Bima \\ Email: sulistiaindah_bk@stkipbima.ac.id
}

\begin{abstract}
Abstrak :
Lingkungan keluarga adalah segala sesuatu yang berada di sekitar individu yang merupakan hubungan dan peranan yang sangat penting dalam perkembangan individu yang mempunyai ikatan- ikatan, baik ikatan perkawinan, darah ataupun adopsi. Kemandirian belajar diartikan sebagai suatu proses belajar yang terjadi pada diri seseorang, dan dalam usahanya untuk mencapai tujuan belajar orang tersebut dituntut untuk aktif secara individu atau tidak tergantung kepada orang lain seperti melakukan kegiatan belajar tanpa disuruh, melakukan kegiatan belajar secara teratur, memiliki jadwal belajar yang telah disusun sendiri, menyelesaikan tugas-tugas sekolah, melakukan diskusi dengan teman sekelas bila ada pelajaran yang. Pendidikan keluarga adalah fundamental atau dasar dari pendidikan anak selanjutnya. Hasil-hasil pendidikan yang diperoleh anak dalam keluarga menentukan pendidikan anak itu selanjutnya, baik sekolah maupun dalam masyarakat. Keluarga merupakan tempat-tempat lain, pendidikan keluarga merupakan dasar dari pendidikan selanjutnya, karena orang tua adalah pendidik kodrati yang mendidik siswa dengan penuh kasih sayang. Judul dalam penelitian ini adalah Korelasi antara lingkungan keluarga dengan kemandirian belajar siswa kelas VIII SMP Negeri 7 Kota Bima. Penelitian ini menggunakan pendekatan kuantitatif yaitu yang bertujuan untuk melihat pengaruh dua variabel yaitu Lingkungan keluarga $(X)$ dan Kemandirian belajar siswa $(Y)$. Instrumen yang digunakan dalam penelitian ini adalah angket dan dokumentasi. Untuk pengujian hipotesis digunakan metode statistika dengan rumus korelasi product moment. Jumlah populasi dalam penelitian ini adalah 171 orang siswa yang tersebar dari 6 kelas, sampel dalam penelitian ini sebanyak 34 orang siswa yang diambil dengan cara acak (Random sampling). Teknik Analisis data adalah Teknik yang di pilih dalam masalah korelasi dua variabel, yang tepat adalah analisis statistika product moment. Dengan bersandar pada hasil analisis data di lapangan yaitu dengan diperolehnya nilai $r$ hitung sebesar 0,763 dikonversikan pada nilai $r$ tabel yang diperoleh dari $N=34$ adalah sebesar 0,126 dengan taraf signifikansi sebesar 5\%. Dari hasil tersebut diketahui bahwa nilai $r$ hitung lebih besar dari nilai $r$ tabel $(0,763$ > 0,126). Berdasarkan hasil analisis data penelitian, maka dapat diambil kesimpulan bahwa : Ada Korelasi antara lingkungan keluarga dengan kemandirian belajar siswa kelas VIII SMP Negeri 7 Kota Bima.
\end{abstract}

Kata Kunci : Lingkungan Keluarga, Kemandirian Belajar 


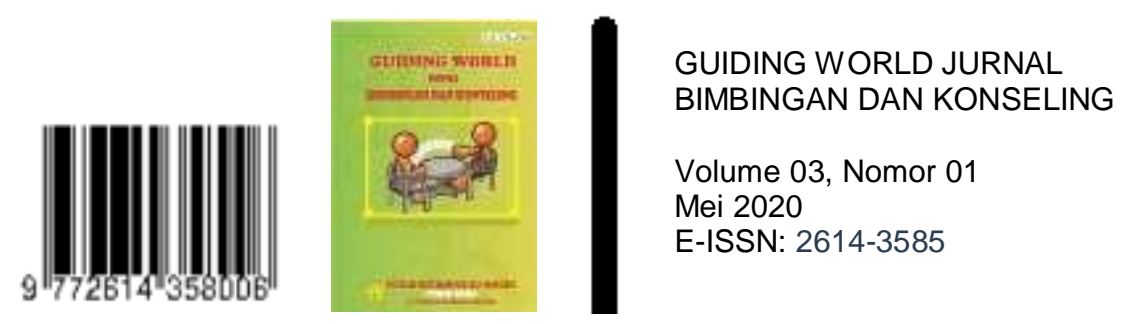

DOI: 1033627

\section{PENDAHULUAN}

Pada lembaga sekolah pada hakekatnya murid dipandang sebagai subyek pendidikan atau dijadikan sarana kegiatan dalam suatu proses belajar, disini dukungan keluarga berperan sangat penting dan tangung jawab yang utama tindakan orang tua untuk mendorong anak serta menyekolahkannya kelembaga pendidikan dengan harapan nantinya lebih mampu untuk mengembangkan minat guna meningkatkan prestasi belajar. Menurut Saodah (2007:2) bahwa "Keluarga merupakan lingkungan pertama dan utama dalam pendidikan, memberikan landasan dasar bagi proses belajar pada pihak sekolah dan masyarakat". Demi keberhasilan anak, berbagai kebutuhan belajar anak diperhatikan dan dipenuhi meskipun dalam bentuk dan jenis yang berbeda. Hal ini sependapat pula dengan Barnadib (2002: 207) yang menyatakan bahwa "Walaupun anak sudah masuk sekolah, tetapi harapan masih digantungkan kepada keluarga untuk memberikan pendidikan dan suasana sejuk dan menyenangkan bagi belajar anak dalam belajar di rumah. Sistem kekerabatan yang baik merupakan jalinan sosial yang menyenangkan bagi anak. Lingkungan keluarga merupakan lingkungan pertama dan utama dalam mendidik dan mengembang sikap serta waktu siswa dalam belajar termasuk di dalam menciptakan kemandirian belajar anak/siswa atau dalam arti kemandirian mempengaruhi kemandirian siswa dalam belajar.

Menurut Ali (2001:52) "Kemandirian merupakan suatu kecederungan menggunakan kemampuan diri sendiri untuk menyelesaikan suatu masalah secara bebas, progresif, dan penuh dengan inisiatif'. Kemandirian belajar menekankan pada aktivitas siswa dalam belajar yang penuh tanggung jawab atas keberhasilannya dalam belajar. Dengan demikian, melalui kemandirian belajar akan mengembangkan aspek kognitif yang tinggi, hal ini disebabkan karena terbiasa menghadapi tugas dan sumber belajar yang ada, serta mengadakan diskusi dengan teman bila menghadapi kesulitan.

Kemandirian siswa dalam belajar akan terwujud apabila siswa aktif mengontrol sendiri segala sesuatu yang dikerjakan, mengevaluasi dan selanjutnya merencanakan sesuatu yang lebih dalam pembelajaran yang dilalui dan siswa mau aktif di dalam proses pembelajaran yang ada. Faktor Kemandirian belajar memegang peranan penting dalam hal kebutuhan manusia baik yang dirasakan maupun yang diceritakan demikian pula dengan kesadaran pendidikan, tidak luput dari pengaruh Lingkungan keluarga para siswa. Kondisi ril dilapangan inilah yang penulis dapat dari survei pendahuluan, bahwa siswa yang berada di SMP Negeri 7 Kota Bima tersebut menunjukan Kemandirian belajar yang dimiliki oleh siswa kurang mendukung dalam meningkatkan prestasi belajar siswa karena kemandirian belajar yang dimiliki oleh siswa tersebut rendah.

Rumusan masalah Korelasi antara lingkungan keluarga dengan kemandirian belajar siswa di SMP Negeri 7 Kota Bima.

\section{KERANGKA TEORITIS DAN PENGEMBANGAN HIPOTESIS}

\section{Lingkungan Keluarga}

Lingkungan keluarga adalah lingkungan terkecil dalam kestuan masyarakat. Keluarga dibangun dari sebuah perkawinan antara seorang laki-laki dengan seorang wanita, kemudian hidup bersama dan menghasilkan keturunan berupa anak. Maka yang bertanggung jawab dalam sebuah keluarga adalah orang tua. Hal tersebut seperti yang dikemukakan oleh Gunarsa 


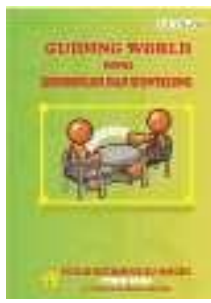

(2009 : 5) bahwa lingkungan keluarga merupakan "lingkungan pertama yang mula-mula memberikan pengaruh yang mendalam bagi anak". Dari anggota-anggota keluarganya (ayah, ibu dan saudara-saudaranya) anak memperoleh segala kemampuan dasar, baik intelektual maupun sosial. Setiap sikap, pandangan dan pendapat orang tua atau anggota keluarga lainnya akan dijadikan contoh oleh anak dalam berperilaku. Demikian juga dengan pendapat Sadjaah (2002) yang mengemukakan bahwa "Lingkungan keluarga merupakan unit terkecil dalam masyarakat memiliki nuclear family maupun extended family, yang secara nyata mendidik kepribadian seseorang dan mewariskan nilai-nilai budaya melalui interaksi sesame anggota dalam mencapai tujuan". Dalam hal ini berarti lingkungan keluarga sebagai lingkungan pendidikan yang pertama ini sangat penting dalam membentuk pola kepribadian anak. Karena di dalam keluarga, anak pertama kali mendapat pengetahuan tentang nilai dan norma.

Pendapat lainnya tentang lingkungan keluarga yaitu menurut Hasbullah (2008:38) yaitu "Lingkungan keluarga merupakan lingkungan pendidikan pertama dan utama bagi anak, karena dalam keluarga inilah anak pertama-tama mendapat didikan dan bimbingan. Dan dikatakan sebagai lingkungan yang utama karena sebagian besar dari kehidupan anak adalah di dalam keluarga." Kemudian Barnadib (2002 : 120) mengemukakan "lingkungan keluarga yaitu lingkungan yang bertanggung jawab atas kelakuan, pembentukkan kepribadian, kasih sayang, perhatian, bimbingan, kesehatan dan suasana rumah. Dari lingkungan keluarga yang harmonis yang mampu memancarkan keteladanan kepada anak-anaknya, akan lahir anak-anak yang memliki kepribadian dengan pola yang mantap, Sementara dalam Undang-Undang Sistem Pendidikan Nasional No. 2/1989 menyatakan secara jelas bahwa keluarga merupakan bagian dari jalur pendidikan luar sekolah yang memberikan keyakinan agama, nilai budaya, nilai-nilai moral, dan keterampilan. Di lingkungan keluarga anak mendapatkan perhatian, kasih sayang, dorongan, bimbingan, keteladanan dan pemenuhan kebutuhan ekonomi dari orang tua sehingga anak dapat mengembangkan segala potensi yang dimilikinya demi perkembangannya di masa mendatang

Dari uraian-uraian tersebut, maka dapat disimpulkan bahwa lingkungan keluarga adalah segala sesuatu yang berada di sekitar individu yang merupakan hubungan dan peranan yang sangat penting dalam perkembangan individu yang mempunyai ikatan-ikatan, baik ikatan perkawinan, darah ataupun adopsi. dan lingkungan keluarga juga adalah segala sesuatu yang disekelilingi manusia yang dapat mempengaruhi tingkah laku secara langsung maupun tidak langsung. Kehidupan manusia selalu berhubungan dengan lingkungan yang didalamnya diperlukan suatu interaksi dengan sesama manusia, baik secara individual maupun kelompok, sebab bagaimanapun manusia tumbuh dan berkembang terutama di lingkungannya.

\section{Peran Lingkungan Keluarga}

Keluarga sudah dikenal sebagai lingkungan perndidikan yang pertama dan utama, (Gunarso, 2000:33). Predikat ini mengindikasikan betapa esensialnya peran dan pengaruh lingkungan keluarga dalam pembentukan perilaku dan kepribadian anak. Pandangan ini sangat logis dan mudah dipahami karena beberapa alaan sebagai berikut:

Pertama, keluarga lazimnya merupakan pihak yang paling awal memberikan banyak perlakuan kepada anak. Begitu anak lahir, lazimnya pihak keluargalah yang langsung menyambut dan memberikan layanan interaktif kepada anak. Apa yang dilakukan dan diberikan oleh pihak keluarga menjadi sumber perlakuan pertama yang akan mempengaruhi 


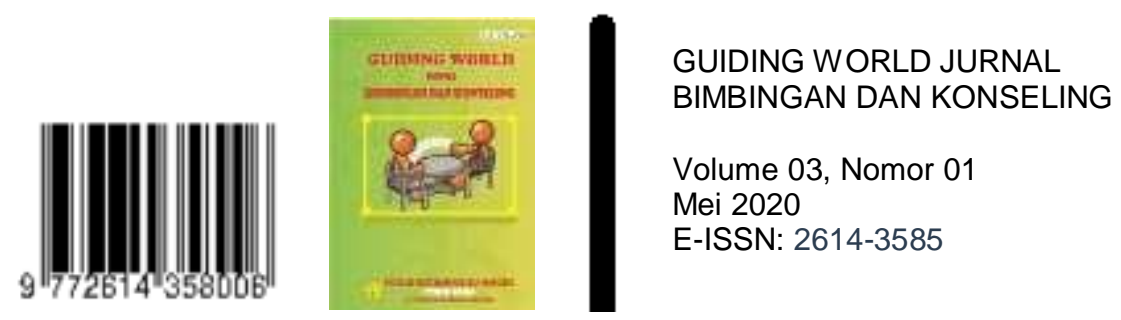

DOI: 1033627

pembentukan karakteristik pribadi dan perilaku anak. Menurut banyak ahli pengalaman hidup pada masa awal akan menjadi fondasi bagi proses perkembangan dan pembelajran anak selanjutnya.

Kedua, sebagian besar waktu anak lazimnya dihabiskan di lingkungan keluarga. Kalau di sekolah anak menghabiskan waktu sekitar 5-6 jam, maka di rumah anak bisa menghabikan waktu sekitar dua kali lipat atau lebih dari itu. Besarnya peluang dan interaksi akan sangat besar pengaruhnya pada perkembangan anak.

Ketiga, karakteristik hubungan orangtua- anak berbeda dari hubungan anak dengan pihak-pihak lainnya (guru, teman, dsb). Kepada orangtua disamping anak memiliki ketergantungan secara materi, ia juga memiliki ikatan psikologi tertentu yang sejak dalam kandungan sudah dibangun melalui jalinan kasih saying dan pengaruh- pengaruh normatif tertentu.Keempat, interaksi kehidupan orangtua- anak di rumah bersifat "asli", seadanya dan tidak dibuat-buat.

\section{Fungsi Lingkungan Keluarga}

Pada dasarnya, keluarga memiliki tanggung jawab atas tiap-tiap anggotanya dimanadalam keluarga diselenggarakan fungsi keluarga. Fungsi keluarga adalah suatu pekerjaan - pekerjaan atau tugas - tugas yang harus dilaksanakan di dalam atau oleh keluarga itu sendiriuntuk menumbuhkembangkan angoota-anggotanya. Pekerjaan-pekerjaan yang harus dikerjakan oleh keluarga itu dapat digolongkan ke dalam beberapa fungsi, (Hasbullah, 2008:12) yaitu : a. Fungsi Biologis, b. Fungsi Ekonomi,c. Fungsi Pemeliharaan, d. Fungsi Keagamaan, e. Fungsi Sosial, dan f. Fungsi Sosialisasi dan Pendidikan

\section{Karakteristik Keluarga}

Adapun karakteristik keluarga yang juga terdapat pada semua keluarga dan juga untuk membedakan keluarga dari kelompok-kelompok sosial. Menurut Gunarso (200:39) ada empat karakteristik keluarga yaitu:

a. Keluarga adalah susunan orang-orang yang disatukan oleh ikatan- ikatan perkawinan darah atau adopsi.

b. Anggota-anggota keluarga ditandai dengan hidup bersama dibawah satu atap merupakan susunan satu rumah tangga, atau jika mereka bertempat tinggal, rumah tangga tersebut menjadi rumah mereka.

c. Keluarga merupakan kesatuan dari orang-orang yang berinteraksi dan berkomunikasi yang menciptakan perana-peranan sosial bagi suami dan istri, ayah, ibu, putra dan putri, saudara laki-laki dan saudara perempuan.

d. Keluarga adalah pemelihara suatu kebudayaan bersama, yang diperoleh pada hakikatnya dari kebudayaan umum, tetapi dalam suatu masyarakat yang komplek masing-masing keluarga mempunyai ciri-ciri yang berlainan dengan keluarga lainnya. Berbedanya kebudayaan dari setiap keluarga timbul melalui kominikasi anggota-anggota keluarga yang merupakan gabungan dari pola-pola tingkah laku individu.

\section{Faktor-Faktor yang Mempengaruhi Perkembangan Anak dalam Lingkungan Keluarga}

Seiring perjalanan hidupnya yang diwarnai faktor internal (kondisi fisik, psikis dan moralitas anggota keluarga) dan faktor eksternal (perubahan sosial budaya, maka setiap 


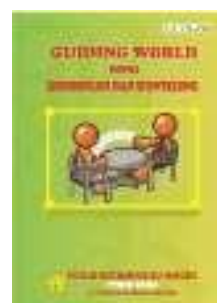

keluarga mengalami perubahan yang beragam. Ada keluarga yang kokoh dalam menerapkan fungsinya (fungsinonal- normal) tapi ada juga keluarga yang mengalami keretakan atau ketidakharmonisan (disfungsional atau tidak normal). Keluarga yang fungsional (normal) yaitu kelurga yang telah mampu melaksanakan fungsinya sebagai mana yang sudah dijelaskan. Disamping itu, keluarga yang fungsional ditandai oleh karakteristik : saling memperjatikan dan mencintai, bersikap terbuka dan jujur, orang tua mau mendengarkan anak,menerima perasaannya dan menghargai pendapatnya, dan ada "sharing" masalah atau pendapat diantara anggota keluarga.

\section{Kemandirian Belajar}

Mandiri berarti mampu bertindak sesuai keadaan tanpa meminta atau tergantung pada orang lain. Mandiri adalah dimana seseorang mau dan mampu mewujudkan kehendak/keinginan dirinya yang terlihat dalam tindakan/perbuatan nyata guna menghasilkan sesuatu (barang/jasa) demi pemenuhan kebutuhan hidupnya dan sesamanya (Antonius, 2002:145). Sementara Kemandirian menurut Eddy Wibwo (1992:69)) adalah sebagai tingkat perkembangan seseorang dimana ia mampu berdiri sendiri dan mengandalkan kemampuan dirinya sendiri dalam melakukan berbagai kegiatan dan menyelesaikan berbagai masalah yang dihadapi. Sedangkan Kemandirian Menurut Masrun (2001:8) adalah suatu sikap yang memungkinkan seseorang untuk bertindak bebas, melakukan sesuatu atas dorongan sendiri dan untuk kebutuhannya sendiri tanpa bantuan dari orang lain, maupun berpikir dan bertindak original/kreatif, dan penuh inisiatif, mampu mempengaruhi lingkungan, mempunyai rasa percaya diri dan memperoleh kepuasan dari usahanya. Sedangkan Belajar diartikan sebagai suatu proses usaha yang dilakukan individu untuk memperoleh suatu perubahan perilaku yang baru secara keseluruhan, sebagai hasil dari pengalaman individu itu sendiri dalam interaksi individu dengan lingkungannya.

Dari beberapa pendapat para ahli dapat disimpulkan bahwa kemandirian belajar adalah kondisi aktifitas Belajar yang mandiri tidak tergantung pada orang lain, memiliki kemauan, inisiatif serta bertanggung jawab sendiri dalam menyelesaikan masalah belajarnya. Kemandirian Belajar akan terwujud apabila siswa aktif mengontrol sendiri segala sesuatu yang dikerjakan, mengevaluasi dan selanjutnya merencanakan sesuatu yang lebih dalam pembelajaran yang dilalui dan siswa juga mau aktif dalam proses pembelajaran.

\section{Ciri-ciri Kemandirian Belajar}

Abu Ahmadi (2000:13), merumuskan ciri-ciri kemandirian mandiri sebagai berikut: 1) Mampu mengambil inisiatif. 2) Mampu mengatasi masalah. 3) Penuh ketekunan. 4) Memperoleh kepuasan dari hasil usahanya. 5) Berkeinginan mengerjakan sesuatu tanpa bantuan orng lain. Sementara Menurut Sukarno (2001:64) menyebutkan siswa atau peserta didk yang memiliki ciri-ciri Kemandirian Belajar ditandai dengan hal-hal sebagai berikut: 1) Siswa merencanakan dan memilih kegiatan Belajar sendiri 2) Siswa berinisiatif dan memacu diri untuk Belajar secara terus menerus 3) Siswa dituntut bertanggung jawab dalam Belajar 4) Siswa Belajar secara kritis, logis, dan penuh keterbukaan 5) Siswa Belajar dengan penuh percaya diri. Sedangkan menurut Hiemstra (2001:23), siswa atau peserta didk yang memiilki Kemandirian belajar.memiliki ciri-ciri: a) Siswa tersebut mempunyai tanggung jawab dalam pengambilan keputusan yang berhubungan dengan usaha pembelajaran b) Belajar mandiri 


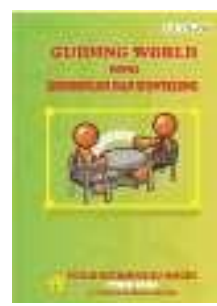

merupakan karakteristik yang dapat digunakan setiap individu dalam setiap situasi c) Belajar mandiri bukan mengisolasi diri individu dengan orang lain d) Individu yang mempunyai Kemandirian Belajar mampu untuk "transfer learning", baik pengetahuan maupun keahlian (skill) dari satu situasi ke situasi yang lain seperti berpartisipasi dalam grup, latihan - latihan, dialog secara elektronik, dan aktifitas-aktifitas menulis. e) Peran efektif dari guru di dalam Belajar mandiri terjadi, seperti melakukan dialog dengan pelajar, melihat sumber pengetahuan yang aman, mengevaluasi hasil yang ada, dan berpikir secara kritis. f) Beberapa institusi pendidikan menemukan cara yang dapat mendukung kemandirian belajar seperti program pendidikan terbuka, pemilihan pendidikan bagi individu, dan program inovasi lainnya.

\section{Faktor-Faktor Yang Mempengaruhi Kemandirian Belajar}

Faktor-Faktor Yang Mempengaruhi Kemandirian Belajar menurut Muhammad Nur Syam (2009:10), terbagi dua factor. Pertama, faktor internal yang ditandai dengan indikator tumbuhnya Kemandirian Belajar yang terpancar dalam fenomena antara lain: a. Sikap bertanggung jawab untuk melaksanakan apa yang dipercayakan dan ditugaskan $b$. Kesadaran hak dan kewajiban siswa disiplin moral yaitu budi pekerti yang menjadi tingkah laku c. Kedewasaan diri mulai konsep diri, motivasi sampai berkembangnya pikiran, karsa, cipta dan karya (secara berangsur) d. Kesadaran mengembangkan kesehatan dan kekuatan jasmani, rohani dengan makanan yang sehat, kebersihan dan olahraga e. Disiplin diri dengan mematuhi tata tertib yang berlaku, sadar hak dan kewajiban, keselamatan lalu lintas, menghormati orang lain, dan melaksanakan kewajiban. Kedua faktor Eksogen atau faktor eksternal. Faktor ini berasal dari luar seperti keluarga, sekolah, dan masyarakat. Faktor ini sebagai pendorong kedewasaan dan Kemandirian Belajar meliputi: potensi jasmani rohani yaitu tubuh yang sehat dan kuat, lingkungan hidup, dan sumber daya alam, sosial ekonomi, keamanan dan ketertiban yang mandiri, kondisi dan suasana keharmonisan dalam dinamika positif atau negatif sebagai peluang dan tantangan meliputi tatanan budaya dan sebagainya secara komulatif

\section{Manfaat Kemandirian Belajar}

Banyak literarur yang mengungkap tentang kelebihan-kelebihan kemandirian belajar (Abdullah, 2011:90) dalam mengutip dari berbagai ahli memaparkan tentang keuntungankeuntungan kemandirian belajar. Orang yang melakukan kegiatan kemandirian belajar mendapatkan keuntungan-keuntungan sebagai berikut:

a. Mempunyai kesadaran dan tanggung jawab yang lebih besar dalam membuat pembelajaran menjadi bermakna terhadap dirinya sendiri.

b. Menjadi lebih penasaran untuk mencoba hal-hal baru.

c. Siswa pada kemandirian belajar memandang permasalahan sebagai tantangan yang harus dihadapi, minat belajar terus berkembang dan pembelajaran lebih menyenangkan.

d. Mereka menjadi termotivasi dan gigih, mandiri, disiplin-diri, percaya diri dan berorientasi pada tujuan.

e. Memungkinkan mereka belajar dan bersosialisasi dengan lebih efektif.

f. Mereka lebih mampu untuk mencari informasi dari berbagai sumber, menggunakan berbagai strategi untuk mencapai tujuan, dan dapat mengungkapkan gagasannya dengan format yang berbeda atau lebih kreatif. 


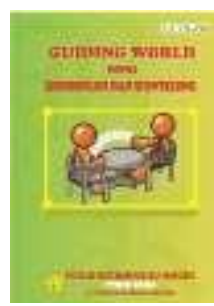

\section{METODE}

Dalam penelitian ini cara pendekatan yang digunakan adalah pendekatan empiris dengan jenis kuantitatif korelasional. Populasi penelitian adalah seluruh siswa kelas VIII yang terdiri dari kelas VIII-A, VIII-B, VIII-C, VIII-D, VIII-E, dan VIII-F pada SMP Negeri 7 Kota Bima yang berjumlah 171 orang. Sampel yang diambil yaitu $25 \%$ dari populasi sehingga besarnya jumlah sampel yang akan digunakan dalam penelitian ini adalah sebanyak $20 \% \mathrm{x}$ $171=34$ orang siswa. Sedangkan untuk pengambilan sampel melalui simple random sampling (cara acak). Instrumen penelitian menggunakan angket dan dokumentasi. Tehnik analisa data yang digunakan adalah korelasi produk moment.

\section{HASIL DAN PEMBAHASAN (12pt bold Styles Heading 1)}

1. Penyajian Subyek Penelitian

Jumlah Siswa Kelas VIII SMP Negeri 7 Kota Bima yang menjadi subyek dalam Penelitian. Adapun data selengkapnya dapat dilihat pada tabel berikut ini:

Tabel 4.1 Data Siswa Kelas VIII SMP Negeri 7 Kota Bima yang menjadi sampel dalam penelitian.

\begin{tabular}{|l|l|l|l|}
\hline No & NIS & Nama Siswa & Kelas \\
\hline 1 & 9000 & AG & VIII-A \\
\hline 2 & 9003 & AK & VIII-A \\
\hline 3 & 9007 & AG & VIII-A \\
\hline 4 & 9026 & AR & VIII-A \\
\hline 5 & 9028 & AK & VIII-A \\
\hline 6 & 9039 & DD & VIII-A \\
\hline 7 & 9049 & EK & VIII-B \\
\hline 8 & 9067 & FH & VIII-B \\
\hline 9 & 9070 & GK & VIII-B \\
\hline 10 & 9075 & HM & VIII-B \\
\hline 11 & 9076 & HY & VIII-B \\
\hline 12 & 9082 & IA & VIII-B \\
\hline 13 & 9073 & HS & VIII-C \\
\hline 14 & 9077 & HK & VIII-C \\
\hline 15 & 9079 & HK & VIII-C \\
\hline 16 & 9084 & IM & VIII-C \\
\hline 17 & 9085 & II & VIII-C \\
\hline 18 & 9129 & ND & VIII-D \\
\hline 19 & 9136 & ND & VIII-D \\
\hline 20 & 9140 & NH & VIII-D \\
\hline 21 & 9141 & NH & VIII-D \\
\hline 22 & 9146 & PP & VIII-D \\
\hline 23 & 9153 & RS & VIII-D \\
\hline 24 & 9154 & RA & VIII-E \\
\hline
\end{tabular}




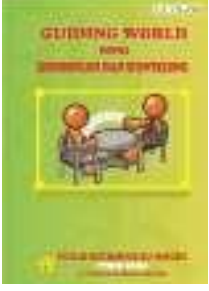

DOI: 1033627

Volume 03, Nomor 01

Mei 2020

E-ISSN: 2614-3585

\begin{tabular}{|l|l|l|l|}
\hline 25 & 9155 & RS & VIII-E \\
\hline 26 & 9160 & SI & VIII-E \\
\hline 27 & 9163 & SI & VIII-E \\
\hline 28 & 9166 & SA & VIII-E \\
\hline 29 & 9133 & NA & VIII-F \\
\hline 30 & 9157 & RI & VIII-F \\
\hline 31 & 9161 & SA & VIII-F \\
\hline 32 & 9162 & RR & VIII-F \\
\hline 33 & 9177 & YK & VIII-F \\
\hline 34 & 9178 & YM & VIII-F \\
\hline
\end{tabular}

Sumber Data: Daftar Hadir Siswa Kelas VIII SMP Negeri 7 Kota Bima

\section{Data Hasil Angket}

Dari hasil pengumpulan dan pengolahan data diperoleh skor angket tentang lingkungan keluarga dan kemandirian belajar. Berikut disajikan data skor angket tentang lingkungan keluarga dan kemandirian belajar.

Tabel 4.2 Skor Angket Lingkungan Keluarga (X) dan Kemandirian Belajar (Y)

\begin{tabular}{|l|l|l|l|}
\hline No & Nama Siswa & X & Y \\
\hline 1 & AG & 22 & 20 \\
\hline 2 & AK & 24 & 25 \\
\hline 3 & AI & 28 & 29 \\
\hline 4 & AR & 27 & 28 \\
\hline 5 & AK & 22 & 25 \\
\hline 6 & DD & 29 & 30 \\
\hline 7 & EH & 28 & 30 \\
\hline 8 & FH & 26 & 25 \\
\hline 9 & GK & 26 & 27 \\
\hline 10 & HM & 26 & 25 \\
\hline 11 & HY & 26 & 25 \\
\hline 12 & IA & 28 & 27 \\
\hline 13 & HS & 29 & 28 \\
\hline 14 & HK & 27 & 29 \\
\hline 15 & HK & 27 & 27 \\
\hline 16 & IM & 25 & 27 \\
\hline 17 & II & 22 & 25 \\
\hline 18 & ND & 25 & 25 \\
\hline 19 & ND & 20 & 25 \\
\hline 20 & NH & 25 & 20 \\
\hline 21 & NH & 20 & 25 \\
\hline 22 & PP & 22 & 20 \\
\hline & & & \\
\hline & NP & (2) \\
\hline
\end{tabular}


Volume 03, Nomor 01

Mei 2020

E-ISSN: 2614-3585

DOI: 1033627

\begin{tabular}{|l|l|l|l|}
\hline 23 & RS & 24 & 22 \\
\hline 24 & RA & 24 & 24 \\
\hline 25 & RS & 30 & 30 \\
\hline 26 & SI & 25 & 30 \\
\hline 27 & SI & 20 & 25 \\
\hline 28 & SA & 25 & 20 \\
\hline 29 & NA & 30 & 30 \\
\hline 30 & RI & 20 & 30 \\
\hline 31 & SA & 20 & 20 \\
\hline 32 & RR & 26 & 28 \\
\hline 33 & YK & 25 & 26 \\
\hline 34 & YM & 24 & 29 \\
\hline
\end{tabular}

Sumber Data: Hasil Angket yang Diolah

\section{Analisis Data dan Pengujian Hipotesis}

Untuk memudahkan melakukan perhitungan analis data perlu dibuat sebuah tabel kerja sebagai berikut:

Tabel 4.3 Tabel kerja untuk menghitung analisis korelasi Product moment

\begin{tabular}{|c|c|c|c|c|c|}
\hline No & $X$ & $\mathrm{Y}$ & $X^{2}$ & $\mathrm{Y}^{2}$ & X.Y \\
\hline 1 & 22 & 20 & 484 & 400 & 440 \\
\hline 2 & 24 & 25 & 576 & 625 & 600 \\
\hline 3 & 28 & 29 & 784 & 841 & 812 \\
\hline 4 & 27 & 28 & 729 & 784 & 756 \\
\hline 5 & 22 & 25 & 484 & 625 & 550 \\
\hline 6 & 29 & 30 & 841 & 900 & 870 \\
\hline 7 & 28 & 30 & 784 & 900 & 840 \\
\hline 8 & 26 & 25 & 676 & 625 & 650 \\
\hline 9 & 26 & 27 & 676 & 729 & 702 \\
\hline 10 & 26 & 25 & 676 & 625 & 650 \\
\hline 11 & 26 & 25 & 676 & 625 & 650 \\
\hline 12 & 28 & 27 & 784 & 729 & 756 \\
\hline 13 & 29 & 28 & 841 & 784 & 812 \\
\hline 14 & 27 & 29 & 729 & 841 & 783 \\
\hline 15 & 27 & 27 & 729 & 729 & 729 \\
\hline 16 & 25 & 27 & 625 & 729 & 675 \\
\hline 17 & 22 & 25 & 484 & 625 & 550 \\
\hline 18 & 25 & 25 & 625 & 625 & 625 \\
\hline 19 & 20 & 25 & 400 & 625 & 500 \\
\hline 20 & 25 & 20 & 625 & 400 & 500 \\
\hline 21 & 20 & 25 & 400 & 625 & 500 \\
\hline 22 & 22 & 20 & 484 & 400 & 440 \\
\hline 23 & 24 & 22 & 576 & 484 & 528 \\
\hline 24 & 24 & 24 & 576 & 576 & 576 \\
\hline 25 & 30 & 30 & 900 & 900 & 900 \\
\hline 26 & 25 & 30 & 625 & 900 & 750 \\
\hline 27 & 20 & 25 & 400 & 625 & 500 \\
\hline
\end{tabular}




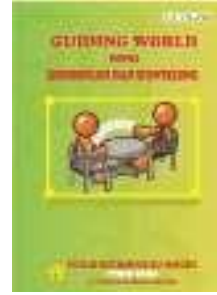

DOI: 1033627

Volume 03, Nomor 01

Mei 2020

E-ISSN: 2614-3585

\begin{tabular}{|l|l|l|l|l|l|}
\hline 28 & 25 & 20 & 625 & 400 & 500 \\
\hline 29 & 30 & 30 & 900 & 900 & 900 \\
\hline 30 & 20 & 30 & 400 & 900 & 600 \\
\hline 31 & 20 & 20 & 400 & 400 & 400 \\
\hline 32 & 26 & 28 & 676 & 784 & 728 \\
\hline 33 & 25 & 26 & 625 & 676 & 650 \\
\hline 34 & 25 & 25 & 625 & 625 & 625 \\
\hline$\sum$ & $\mathbf{1 7 8 2}$ & $\mathbf{1 8 0 3}$ & $\mathbf{7 2 9 2 4}$ & $\mathbf{7 9 2 2 0}$ & $\mathbf{7 5 8 9 1}$ \\
\hline
\end{tabular}

Sumber Data: Hasil Angket yang Diolah

Dari tabel kerja di atas diperoleh nilai-nilai sebagai berikut:

$$
\begin{aligned}
\sum X & =1782 \\
\sum Y & =1803 \\
\sum X^{2} & =72924 \\
\sum Y^{2} & =79220 \\
\sum X Y & =75891
\end{aligned}
$$

$$
\begin{aligned}
& \left(\sum X\right)^{2}=3175524 \\
& \left(\sum Y\right)^{2}=3250809
\end{aligned}
$$

Selanjutnya harga-harga tersebut dimasukkan kedalam rumus untuk memperoleh nilai koefisien hubungan yang di cari melalui rumus sebagai beirkut:

$$
\begin{aligned}
& \mathrm{n} \sum \mathrm{XY}-\left(\sum \mathrm{X}\right)\left(\sum \mathrm{Y}\right) \\
& \mathrm{r} x \mathrm{y}=\frac{}{\sqrt{\left\{\mathrm{n} \sum \mathrm{X}^{2}-\left(\sum X\right)^{2}\right\}\left\{\mathrm{n} \sum \mathrm{Y}^{2}-\left(\sum \mathrm{Y}\right)^{2}\right\}}} \\
& 44(75891) \text { - (1782) (1803) } \\
& r x y=\frac{\sqrt{\{44(72924)-(3175524)\}\{44(79220)}-(3250809)\}}{} \\
& 3339204-3212946 \\
& r x y=\overline{\sqrt{\{(3208656)-3175524\}\{3485680)-3250809\}}} \\
& 126258 \\
& \mathrm{rxy}=\frac{}{\sqrt{(33132)(23471)}} \\
& 126258 \\
& \text { r } \mathrm{x} \mathrm{y}= \\
& \sqrt{777641172} \\
& 126258 \\
& \mathrm{r} \mathrm{x} \mathrm{y}= \\
& 61434,78 \\
& r^{X Y}=0,763
\end{aligned}
$$

Dari hasil perhitungan analisis data diperoleh nilai t-hitung sebesar 0,763 Apakah nila thitung tersebut lebih besar atau lebih kecil dari nilai t-tabel, maka perlu dilakukan perbandingan antara nilai t-hitung dan nilai t-tabel untuk mengetahui apakah kemandirian siswa dalam belajar berpengaruh terhadap hasil belajar siswa, maka perlu dilakukan pengujian hipotesis yaitu apabila t-hitung lebih besar dari t-tabel maka Hipotesis alternatif (Ha) diterima 


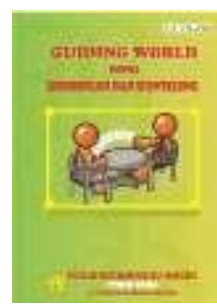

DOI: 1033627

Volume 03, Nomor 01

Mei 2020

E-ISSN: 2614-3585

dan sebaliknya apabila t-hitung lebih kecil dari t-tabel maka Ha ditolak dan Hipotesis nihil (Ho) diterima.

\section{PENUTUP (12pt bold Styles Heading 1)}

Dari hasil analisis data yang ditelah dilakukan dapat disimpulkan bahwa ada pengaruh lingkungan keluarga dengan kemandirian belajar siswa kelas VIII SMP Negeri 7 Kota Bima diterima. Hal tersebut sesuai prosedur pengujian yang telah dilakukan bahwa nilai t-hitung yang diperoleh dalam penelitian ini adalah 0,763 sedangkan nilai t-tabel diketahui bahwa dengan $\mathrm{N}=34-2=32$ dengan taraf signifikan (taraf kesalahan) 5\% adalah 0,126. Dengan demikian, nilai t-hitung lebih besar dari nilai t-tabel yaitu 0,763>0,126. Artinya, semakin baik lingkungan keluarga maka cenderung semakin baik pula kemandirian siswa dalam belajar. Sebaliknya, apabila lingkungan keluarga kurang baik, maka akan berdampak kurang baik pula pada kemandirian siswa dalam belajar.

\section{DAFTAR PUSTAKA}

[1] Abdullah. 2011. Belajar dan Faktor-Faktor Yang Mempengaruhinya. Jakarta: Rineka Cipta.

[2] Ahmadi, A. 2000. Psikologi Pendidikan dan Evaluasi Belajar. Jakarta: Gramedia

[3] Algifari. 2000. Analisis Regresi Teori,Kasus, dan Solusi. Yogyakarta: BPFE.

[4] Ali, Muhammad. 2001. Guru dalam Proses Belajar Mengajar. Bandung: Sinar Baru.

[5] Amir, A. 2010. Pedoman Penulisan Karya Ilmiah. STKIP Bima: CV. Usaha Tunggal.

[6] Antonius, 2002. Hubungan antara Kemandirian dengan prestasi belajar karya kerajinan tangan pada siswa kelas I SD Negeri Bulu Lor 01-03 Semarang tahun pelajaran 2004/2005. "Skripsi" tidak diterbitkan

[7] Arikunto, S. 2002. Prosedur Penelitian Suatu Pendekatan Praktek. Jakarta: Rineka Cipta.

[8] Barnadib, Imam. 2002. Filsafat Pendidikan. Yogyakarta: Adi Citra.

[9] Depdiknas. 2003. Undang-Undang RI No. 20 Tahun 2003 Tentang Sistem Pendidikan Nasional (SISDIKNAS). Jakarta: Depdiknas.

[10] Susilawati, D. 2009. Kemandirian Belajar dan Faktor-Faktor Yang Mempengaruhinya. Jakarta: Rineka Cipta.

[11] Wibowo, E. 1992. Evaluasi Pengajaran (Prinsip dan Teknik). Bandung: Remaja Rosdakarya

[12] Gunarso, D Singgih. 2000. Psikologi Praktis, anak, Remaja, dan Keluarga. Jakarta : BPK Gunung Mulia.

[13] Haris Mujiman, 2005. Meningkatkan Kemandirian Belajar Simposium Peranan Psikilogi dalam Usaha Meningkatkan Prestasi Belajar. Surabaya, Sie Psikologi, bag. Psikiatri Fakultas Kedokteran UNAIR.

[14] Hasbullah. 2008. Peran Keluarga dalam Mencerdaskan anak. Jakarta : BPK Gunung Mulia.

[15] Iswardono. 1981. Analisa Regresi dan Korelasi. Yogyakarta: BPFE UGM.

[16] Masrun, 2001. Pengaruh Kemandirian belajar tehadap hasil belajar pada mata pelajaran Ekonomi pada siswa kelas XI IPS SMA Negeri 2 Semarang tahun pejaran 2005/2006. "Skripsi" tidak diterbitkan. 
DOI: 1033627

Volume 03, Nomor 01

Mei 2020

E-ISSN: 2614-3585

[17] Moleong, L,J. 2000. Metode Penelitian Kualitatif. Bandung: PT. Remaja Rosdakarya.

[18] Riduwan, 2004. Belajar Mudah Penelitian Untuk Guru-Karyawan dan Peneliti Pemula. Alfabeta Bandung

[19] Sadojah. 2002, Pengantar Bimbingan dan Penyuluhan Belajar di Sekolah. Surabaya; Usaha Nasional

[20] Saodah, Sukmadinata, N. 2007. Bimbingan dan Konseling. Bandung: Maestro.

[21] Sadirman, AM, 1986. Interaksi dan Motivasi Belajar Mengajar. Jakarta : Rajawali.

[22] Slavin, 2004. Prestasi belajar dan Kompetensi Guru. Jakarta : Gramedia 